\title{
Analisis Pelaksanaan Asesmen Perkembangan Anak
}

\author{
Delia Nuralita Fajri, Nanik Yuliati, Luh Putu Indah Budyawati \\ Pendidikan Anak Usia Dini, Fakultas Keguruan dan Ilmu Pendidikan, Universitas Jember \\ Jl. Kalimantan 37, Jember 68121 \\ E-mail : nanikyuliati@gmail.com
}

\begin{abstract}
Abstrak
Penelitian ini mendeskripsikan tentang analisis pelaksanaan asesmen perkembangan anak pada anak kelompok A2 di TK Dharma Wanita Tegal Gede Tahun Ajaran 2018-2019. Informan dalam penelitian ini yaitu guru kelas kelompok A2 dan kepala sekolah. Penelitian yang dilakukan menggunakan penelitian deskriptif kualitatif. Berdasarkan hasil identifikasi pelaksanaan asesmen di TK Dharma Wanita Tegal Gede, adalah: guru telah melakukan kegiatan asesmen dengan baik dari perencanaan hingga proses dilakukannya asesmen di kelas. Sebelum memasukkan nilai pada buku bantu harian anak didik, guru setiap hari membuat catatan kecil dengan lingkaran hitam untuk anak mampu dan lingkaran putih untuk anak tidak mampu. Anak yang mampu mendapat huruf $\mathrm{B}$ dan yang tidak mampu mendapat huruf $\mathrm{C}$, dalam hal ini asesmen yang digunakan memiliki kelemahan berupa huruf B dan C, yang kurang spesifik digunakan untuk mengetahui perkembangan masing-masing anak. Hasil asesmen harian belum digunakan sebagai informasi perkembangan anak selama di sekolah kepada orang tua
\end{abstract}

\section{Abstract}

The purpose of this study to describes the analysis of the implementation of child development in children group A2 in the Dharma Wanita Tegal Gede Kindergarten in 2018-2019 Academic Year. The informants in this study were A2 group teacher and the principal. This Research conducted was used qualitative descriptive research. Based on the results of the identification of the implementation of the assessment at Dharma Wanita Tegal Gede Kindergarten, the teacher has carried out assessment activities well from planning to the process of conducting assessment in the classroom. Before entered the scores on student's daily help books, the teacher makes a small note every day with dark circles for capable children and white circles for poor children. Children who are able to get the B score and who are not able to get the C score, the assessment of this case used has the weaknesses in the form of $B$ and $C$ score, which are less specifically used to determine the development of each child. Daily assessment results have not been used as information on children's development during school to parents

Keywords : Development Assessment, Assessment Weakness

\section{Pendahuluan}

Penggunaan istilah penilaian, dikenal dengan kata asesmen yang artinya suatu proses untuk mengumpulkan informasi dan mengambil keputusan yang diperoleh melalui pengukuran hasil belajar di sekolah. Setiap hari guru melakukan asesmen (penilaian), seperti contoh merencanakan suatu perencanaan program, yaitu memperhitungkan sasaran yang akan dicapai serta kecapaian program nantinya. Menurut Waseso [1], asesmen adalah mengumpulkan data-data dan melihat kebutuhan anak, kemampuan atau abilitas ketercapaian perkembangan anak didik dalam kegiatannya di sekolah. Asesmen merupakan istilah yang biasa digunakan dari semua metode untuk menilai hasil kerja anak, baik individu ataupun kelompok kecil. Asesmen merujuk pada banyak bukti, salah satunya yaitu pengetahuan serta keterampilan anak didik Waseso [1]. Menurut pendapat Zainul dan Mulyana [2] bahwa asesmen (penilaian) yaitu memberikan nilai tentang kualitas sesuatu. Tidak hanya sekedar mencari jawaban terhadap pertanyaan tentang apa, tetapi lebih di arahkan kepada menjawab pertanyaan bagaimana atau seberapa jauh proses tersebut dicapai. Asesmen menurut Dariyanto (2010:130) adalah suatu proses untuk menyimpulkan hasil pengukuran melalui analisis yang sistematis dengan menggunakan kriteria seperti baik, buruk, cocok tidak cocok sesuai dengan penilaian kriteria masing-masing [3]. Pada proses pembelajaran di TK, banyak hal yang perlu diperhatikan dalam keseharian anak. Misalnya model pembelajaran, dampak yang terjadi pada kegiatan tertentu dalam proses pembelajaran baik yang positif maupun negatif, yang akan diperoleh anak didik. Semua aspek dalam lingkup anak usia dini memang dapat di analisis, termasuk analisis hasil asesmen perkembangan anak didik. Asesmen juga melihat seberapa jauh anak dapat berkembang sehingga dapat digunakan juga untuk melihat tahap perkembangan anak selanjutnya serta proses-proses dalam asesmen yaitu melihat kebutuhan perkembangan anak, mengumpulkan data untuk mendapat informasi dari asesmen yang dibuat dan melakukan penarikan kesimpulan [4]. Asesmen menilai seluruh aspek perkembangan anak mulai perkembangan moral agama, kognitif, bahasa, sosial 
emosional, fisik motorik, dan perkembangan seni. Perkembangan anak merupakan hal yang penting yang harus dipahami guru, menjadi dasar bagi pendidik dalam mengembangkan kegiatan pembelajaran yang sesuai dengan usia, minat, dan kebutuhan anak. Untuk merancang kegiatan yang sesuai dengan indikator-indikator perkembangan, guru perlu melihat kebutuhan anak dan perkembangan anak terlebih dahulu dengan menggunakan asesmen. Asesmen perkembangan yang dibuat oleh guru dapat melihat sejauh mana anak berkembang, sehingga bermanfaat dalam membuat keputusan tentang penyusunan program tindak lanjut yang tepat untuk membantu anak agar berkembang secara optimal, kurikulum dan kebutuhan anak. Menyadari pentingnya asesmen untuk mengetahui perkembangan masing-masing anak menjadi alasan dilaksanakannya penelitian analisis pelaksanaan asesmen perkembangan anak di kelompok A2. Selain pentingnya asesmen, terdapat juga permasalahan anak yang belum mampu menguasai pembelajaran yang diberikan di TK Dharma Wanita Tegal Gede, para guru telah melaksanakan asesmen untuk mengetahui perkembangan anak di kelasnya. Pelaksanaan asesmen dilakukan setiap hari oleh para guru kelas dengan melakukan pencatatan aktivitas serta penilaian yang diberikan kepada anak saat pembelajaran berlangsung dan telah menggunakan kurikulum 2013 (K13).

Hasil obervasi awal dengan guru kelas A2 di TK Dharma Wanita Tegal Gede menunjukkan bahwa perencanaan asesmen yang dilakukan oleh guru kelas di TK tersebut dirasa belum memberikan informasi yang jelas tentang perkembangan anak serta masih ditemui kelemahan pada hasil penilaian perkembangan tersebut. Karena pada dasarnya asesmen (penilaian) digunakan untuk melihat sejauh mana anak telah berkembang, kurang berkembang, bahkan belum berkembang. Penilaian hanya berupa huruf $\mathrm{B}$ dan $C$, nilai B untuk anak yang mampu dan $C$ untuk anak yang tidak mampu sama sekali dalam pembelajaran. Anak yang mampu tetapi masih terdapat kekurangan, juga ditempatkan di huruf C. Saat guru mengetahui ada beberapa anak di kelas yang belum mampu dalam pembelajaran yang diberikan, guru belum melakukan tindak lanjut kepada anak tersebut dan juga belum melaporkan hasil belajar anak selama sehari kepada wali murid.

Berdasarkan uraian di atas, maka proses asesmen sangat penting dilakukan, namun di TK Dharma Wanita Tegal Gede masih terdapat beberapa kelemahan dari asesmen yang masih perlu dilakukan identifikasi. Oleh karena itu, penelitian dengan judul "Analisis Pelaksanaan Asesmen Perkembangan Anak Pada Anak" dinilai patut dilaksanakan dan nantinya akan ada evaluasi untuk perbaikan penilaian

\section{Metode Penelitian}

Jenis penelitian menggunakan penelitian deskriptif kualitatif. Waktu penelitian direncanakan sekitar 2 minggu dalam mengkaji analisis pelaksanaan asesmen perkembangan belajar anak di TK Dharma Wanita Tegal Gede Jember. Dalam waktu 2 minggu tersebut, harus dapat digunakan sebaik-baiknya dalam mengumpulkan data-data dari lapangan. Sukmadinata dan Nana (2009:18), menyatakan bahwa penelitian deskriptif bertujuan mendeskripsikan suatu keadaan atau fenomena secara apa adanya [5]. Penelitian kualitatif, penelitian yang digunakan untuk mendeskripsikan dan menganalisis aktivitas sosial, sikap, fenomena, peristiwa, presepsi, kepercayaan, serta orang secara individual maupun kelompok [5].

Tempat penelitian merupakan tempat yang akan digunakan sebagai tempat pelaksanaan penelitian. Lokasi penelitian ini yang dipilih yaitu di TK Dharma Wanita Tegal Gede, berdasarkan pertimbangan sebagai berikut : a) Tempat terjadinya masalah yang ingin diteliti yaitu di TK Dharma Wanita Tegal Gede. b) Peneliti ingin mengetahui bagaimana pelaksanaan asesmen perkembangan belajar anak pada anak kelompok A2 di TK Dharma Wanita Tegal Gede Jember. Pada penelitian kualitatif responden atau subjek penelitian disebut dengan istilah informan, yaitu orang memberi informasi tentang data yang diinginkan peneliti berkaitan dengan penelitian yang sedang dilaksanakan. Subjek penelitian merupakan orang yang dapat memberikan keterangan atau penjelasan terhadap suatu permasalahan yang diselidiki. Subjek dalam penelitian ini adalah guru kelas kelompok A2 dan kepala sekolah TK Dharma Wanita Tegal Gede Jember. Penelitian tersebut berdasarkan alasan bahwa TK Dharma Wanita Tegal Gede sudah melaksanakan asesmen perkembangan belajar kepada anak tetapi masih perlu dilakukan evaluasi pada asesmen tersebut.

Data merupakan kumpulan fakta atau informasi yang dapat terbentuk angka atau deskriptif yang berasal dari sumber data. Data dalam penelitian ini adalah subyek dari data yang dapat diperoleh dari hasil observasi, dokumentasi, tes. Sumber data diperoleh dari Informan kunci yaitu guru kelas dan kepala Sekolah TK Dharma Wanita Tegal Gede. Menurut Sukmadinata (2011: 73), penelitian deskriptif kualitatif ditujukan untuk mendeskripsikan dan menggambarkan fenomena-fenomena yang ada, baik bersifat alamiah maupun rekayasa manusia, yang lebih memperhatikan mengenai karakteristik, kualitas, keterkaitan antar kegiatan [6]. penelitian deskriptif kualitatif yaitu rangkaian kegiatan untuk memperoleh data yang bersifat apa adanya tanpa ada dalam kondisi tertentu yang hasilnya lebih menekankan proses. Dalam penelitian ini, dilakukan untuk menganalisis pelaksanaan asesmen perkembangan belajar anak di TK Dharma Wanita Tegal Gede Kabupaten Jember. Data yang dikumpulkan dari penelitian ini berasal dari dua sumber, yaitu:

a) Data primer, menurut Hasan [7] adalah data yang diperoleh atau dikumpulkan langsung di lapangan oleh orang yang melakukan penelitian. Metode pengambilan data primer yang dilakukan adalah dengan cara observasi langsung melihat penilaian yang dibuat guru dalam kegiatan pembelajaran yang sedang berlangsung di kelompok A2 di TK Dharma Wanita Tegal Gede Jember.

b) Data sekunder, adalah data yang diperoleh atau dikumpulkan oleh orang yang melakukan penelitian dari sumber-sumber yang telah ada [7]. Data ini digunakan untuk mendukung data yang telah ada. Data sekunder yang akan dibuat yaitu berupa dokumen RKH, hasil asesmen, dan lain-lain. 
Sesuai dengan karakteristik data yang diperlukan dalam penelitian ini, maka teknik pengumpulan data yang dilakukan adalah:

a) Observasi merupakan teknik yang mendasar dalam penelitian non tes. Observasi dilakukan dengan pengamatan yang jelas, rinci, lengkap, dan sadar tentang perilaku individu di dalam keadaan tertentu. Pentingnya observasi adalah kemampuan dalam menemukan masalah-masalah yang terdapat di sekolah dan masalah penilaian yang ditemukan di TK Dharma Wanita Tegal Gede kelas A2 yaitu mengenai asesmen perkembangan belajar anak. Melalui observasi, peneliti telah mengetahui bentuk asesmen yang dibuat oleh guru yang terdapat pada kelas A2. Observasi yang dilakukan dalam penelitian kualitatif maka observasi yang digunakan yaitu observasi langsung.

b) Dokumentasi, Adapun data yang ingin diperoleh melalui metode dokumentasi yaitu meliputi: 1) Profil Sekolah, 2) Visi dan Misi di TK Dharma Wanita Tegal Gede, 3) Foto Kegiatan Asesmen di TK Dharma Wanita Tegal Gede, 4) Data siswa Kelompok A2 di TK Dharma Wanita Tegal Gede, 5) Profil guru di TKD Dharma Wanita Tegal Gede, 6) Rancangan Kegiatan Harian, 7) Hasil Asesmen di kelas A2.

c) Wawancara, menurut Moleong [8], wawancara adalah percakapan yang dilakukan oleh dua pihak yaitu terwawancara (interviewee) yang memberikan jawaban dari pertanyaan dan pewawancara (interviewer) yang mengajukan pertanyaan. Selanjutnya, wawancara adalah responden atau interviewee memberikan informasinya secara lisan dalam hubungan tatap muka, sehingga responden dapat menuliskan jawabannya secara tertulis ataupun tidak. Peneliti memperoleh informasi melalui wawancara kepada guru kelas A2 dan Kepala Sekolah TK Dharma Wanita Tegal Gede.

Pengolahan dan analisis data menggunakan analisis deskriptif yang dilakukan untuk menganalisis pelaksanaan asesmen perkembangan belajar anak pada anak kelompok A2 di TK Dharma Wanita Tegal Gede. Penelitian deskriptif adalah penelitian yang didasarkan data deskriptif

keadaan, sikap, hubungan atau sistem pemikiran suatu masalah yang menjadi objek penelitian. Model interaksi dalam analisis data menurut Miles dan Huberman [8] terdapat 4 bagian, antara lain: pengumpulan data, reduksi data, penyajian data dan kesimpulan.

\section{Hasil dan Pembahasan}

Penelitian dilakukan di TK Dharma Wanita Tegal Gede pada anak kelompok A2. TK Dharma Wanita Tegal Gede terletak di Jl. Tawang Mangu No.70 RT.02 RW.03 Lingkung Panji Kelurahan Tegal Gede Kecamatan Sumbersari Kabupaten Jember 68126, telp. 085258874095. Lokasi TK Dharma Wanita bersebelahan dengan SD Negeri Tegal Gede, untuk TK ini berada di belakang kantor kelurahan Tegal Gede dan dekat dengan lingkungan pemukiman warga.

Awal berdirinya TK Dharma Wanita Tegal Gede telah berdiri sejak tahun 1987 di bawah yayasan Dharma Wanita. Terdapat 3 kelas di TK Dharma Wanita Tegal Gede, terdiri dari 2 kelas A yaitu A1 dan A2 dan 1 kelas B. Jumlah murid di kelas A1 sebanyak 21 anak, di kelas A2 sebanyak 18 anak dan di kelas B sebanyak 25 anak, sehingga total semua siswa adalah 64 siswa. TK Dharma Wanita Tegal Gede memiliki 1 kepala sekolah, 3 guru kelas serta 1 guru TU.

Berdasarkan hasil penelitian yang telah dilakukan pada anak kelompok A2 di TK Dharma Wanita Tegal Gede dapat diketahui bahwa pelaksanaan asesmen perkembangan belajar anak telah dilaksanakan setiap hari selama pembelajaran di kelas sedang berlangsung. Data yang diperoleh berdasarkan hasil dari observasi, wawancara dan dokumentasi yang dilakukan selama 2 minggu. Observasi yang dilakukan melalui alat bantu berupa ceklis yang digunakan untuk menilai guru dan catatan lapangan yang digunakan untuk mencatat kegiatan-kegiatan asesmen yang dilakukan guru di kelas. Berikutnya, wawancara untuk mengetahui pelaksanaan asesmen perkembangan anak di kelompok A2, melibatkan kepala sekolah dan guru kelas A2. Terakhir yaitu dokumentasi, hal-hal yang didapatkan dari dokumentasi yaitu melalui pengumpulan dokumen-dokumen sekolah yaitu visi misi, profil sekolah, foto-foto, data siswa, profil guru serta yang mendukung dokumen asesmen, seperti RKH, dan penilaian harian guru di kelas A2. Penyusunan penilaian yang dilakukan oleh guru kelas A2 telah mencakup semua perkembangan yang dibutuhkan anak. Sebelum melakukan penilaian, guru kelas menyiapkan kisi-kisi yang dibuat secara sederhana yang akan digunakan dengan menulisnya di kertas HVS berukuran kecil. Kisi-kisi yang dibuat sesuai dengan Peraturan Menteri Pendidikan dan Kebudayaan Republik Indonesia Nomor 137 Tahun 2014 tentang Standar Nasional Pendidikan Anak Usia Dini mencakup lingkup perkembangan seperti nilai moral dan agama, fisik motorik, kognitif, bahasa, sosial emosional dan seni.

Proses penyusunan asesmen telah dilakukan di TK Dharma Wanita Tegal Gede, meskipun masih terdapat hal yang belum sesuai dengan pernyataan yang dikemukakan oleh Fridani yaitu:

1. Dilakukan individual dengan membandingkan perkembangan anak saat ini dengan perkembangan sebelumnya.

2. Mempertimbangkan adanya perbedaan dalam perkembangan, pengalaman, dan budaya anak.

3. Bukan dilakukan dalam situasi tes, melainkan alamiah.

4. Kemajuan tentang anak dilaporkan dalam konteks individual sehubungan dengan perkembangannya dalam tahap usianya, dan bukan merupakan sistem ranking.

Pembuatan penilaian TK Dharma Wanita Tegal Gede dirasa masih terdapat kekurangan dalam mempertimbangkan perkembangan masing-masing anak pada penyusunan penilaian yang akan diberikan kepada anak. Terdapat beberapa hal yang tidak sesuai dengan pernyataan tersebut yang ditemukan di lapangan yaitu, guru hanya menuliskan perkembangan anak didik setiap hari dan belum mengacu kepada tingkat perkembangan anak yang sesuai dengan usia anak, juga belum melihat kompetensi inti dan kompetensi dasar yang telah dibuat sebagai acuan untuk perkembangan anak dalam pembelajaran setiap hari, penilaian juga belum digunakan untuk membandingkan perkembangan masingmasing anak pada saat ini dan perkembangan sebelumnya. Pembelajaran yang dilakukan di kelas masih banyak 
menggunakan tes, karena guru hanya memberikan materi pembelajaran, kemudian memberi contoh dan memberikan kesempatan anak untuk mengerjakan tetapi belum memperhatikan perkembangan anak pada proses belajar di kelas.

Asesmen yang digunakan di TK Dharma Wanita Tegal Gede menggunakan model asesmen portofolio. Portofolio dipilih oleh kepala sekolah karena dianggap cocok untuk dilaksanakan di sekolah. Pelaksanaan asesmen portofolio di TK Dharma Wanita Tegal Gede memang belum dilaksanakan sepenuhnya karena alat yang diperlukan untuk merekam dan memotret setiap pembelajaran belum memadai. Pelaksanaan model portofolio seharusnya menilai perkembangan dari hasil karya anak didik, serta usaha anak didik selama kegiatan pembelajaran berlangsung dan penilaian seharusnya dilakukan dengan melihat capaian perkembangan anak sesuai usia, tidak hanya dari kegiatan harian anak.

Pelaksanaan asesmen perkembangan anak didik pastinya memiliki tujuan. Sebagaimana dikemukakan oleh Fridani (2011:1.4) bahwa tujuan penilaian meliputi beberapa hal berikut ini yaitu, asesmen melihat perkembangan masingmasing anak, yang meliputi: perkembangan kognitif, sosial emosional, bahasa, moral agama, fisik motorik, dan seni. Digunakan untuk melihat kekurangan dan masalah perkembangan anak dalam mengikuti pembelajaran. Memberikan program yang tepat pada anak, seperti jika terdapat anak yang membutuhkan pelayanan khusus, serta asesmen juga digunakan untuk melihat anak telah berkembang dengan baik atau belum. Pernyataan tersebut sesuai dengan perumusan tujuan yang dijelaskan oleh Kepala Sekolah TK Dharma Wanita Tegal Gede yaitu tujuan asesmen untuk melihat perkembangan masing-masing anak didik, untuk melihat kekurangan dan kemampuan perkembangan anak di kelas. Tetapi ada satu yang belum terlaksana yaitu pelayanan khusus untuk anak yang masih berkembang dengan memerlukan bantuan orang lain. Kegiatan tersebut tidak dilakukan, karena menurut kepala sekolah anak akan merasa makin lelah jika mendapatkan pelajaran tambahan pada saat sepulang sekolah. Jadi, jika terdapat anak yang kurang mampu saat pembelajaran seharihari, maka guru kelas A2 akan mengulanginya melalui pengayaan di akhir pembelajaran semester, atau biasanya mengulanginya melalui RKH yang memiliki indikator yang sama.

Guru harus mengetahui pentingnya asesmen yang akan dilakukan dan diberikan kepada anak, agar tidak salah dalam memilih pembelajaran yang akan diberikan selanjutnya. Asesmen juga salah satu cara bagi guru agar dengan mudah mengetahui perkembangan anak didik. Salah satu cara yang dilakukan Guru dan Kepala Sekolah di TK Dharma Wanita Tegal Gede dimulai dari langkah-langkah yang pertama yaitu penyusunan, mempersiapkan penilaian yang sesuai dengan RKH yang dibuat di sekolah, hingga proses asemen yang melibatkan guru dalam memberikan penilaian terhadap masing-masing anak didik di dalam kelompok A2. Pernyataan tersebut sesuai dengan pendapat Sudjana [10], yang menyatakan bahwa langkah-langkah asesmen adalah sebagai berikut: untuk mempersiapkan alat yang akan digunakan untuk melakukan asesmen. Kemudian, menyusun alat-alat penilaian untuk anak yang cocok digunakan dalam menilai jenis-jenis perkembangan anak didik, selanjutnya untuk melaksanakan asesmen perkembangan anak, dan menentukan hasil penilaian sesuai dengan tujuan penilaian untuk menjelaskan atau menjabarkan kemampuan anak, perbaikan pengajaran oleh guru, serta kepentingan bimbingan belajar.

Hasil pembahasan terhadap pelaksanaan asesmen perkembangan anak pada anak kelompok A2 adalah kegiatan asesmen telah dilakukan meskipun masih terdapat banyak kekurangan dan kelemahan yang di temukan. Pada dasarnya asesmen mempunyai manfaat yang cukup baik bagi guru dan orang tua yang akan digunakan sebagai alat yang digunakan untuk melaporkan hasil belajar anak selama di sekolah, untuk menambah semangat guru dalam mendidik anak didiknya, sebagai perbaikan pembelajaran serta menentukan tindak lanjut yang tepat yang akan diberikan pada anak, apakah akan diberikan pada setiap pengayaan atau pengulangan pembelajaran yang sama yang terdapat pada RKH sehingga guru dapat mengetahui apakah anak tersebut telah berkembang dengan baik atau belum mampu mengembangkan kemampuannya. Kegiatan asesmen telah terbukti dilakukan di TK Dharma Wanita Tegal Gede dengan adanya kegiatan asesmen yang berlangsung setiap hari pada saat pembelajaran. Tetapi, manfaat asesmen tersebut belum dibuktikan oleh guru dan Kepala Sekolah TK Dharma Wanita Tegal Gede, karena TK tersebut belum menggunakan asesmen sebagai alat informasi perkembangan anak pada orang tua, belum digunakan sebagai perbaikan pembelajaran serta/tidak ada tindak lanjut yang diberikan kepada anak. Kegiatan penilaian belum memperlihatkan penilaian perkembangan anak secara spesifik, karena pembuatan penilaian hanya berupa huruf $\mathrm{B}$ dan $\mathrm{C}$ serta banyaknya kendala lainnya yang dialami oleh sekolah.

\section{Kesimpulan dan Saran}

\section{Kesimpulan}

Berdasarkan hasil dan pembahasan, diperoleh kesimpulan bahwa TK Dharma Wanita Tegal Gede telah melaksanakan penyusunan dan proses asesmen bagi anak. Tetapi hasil penilaian didapat dari perkembangan melalui kegiatan harian, belum melalui perkembangan yang sesuai dengan usia anak. Penilaian selanjutnya dimasukkan pada buku bantu harian anak didik berupa huruf $\mathrm{B}$ dan $\mathrm{C}$, dan perencanaan asesmen, guru belum mempertimbangkan penilaian yang sesuai dengan perkembangan sesuai usia anak, asesmen yang dilakukan masih banyak kelemahan serta belum menyesuaikan perkembangan dengan Kompetensi Inti (KI), Kompetensi Dasar (KD), serta model asesmen porotofolio yang belum berjalan dengan baik.

\section{Saran}

Berdasarkan kesimpulan di atas, saran yang diberikan tentang pelaksanaan asesmen perkembangan anak pada anak kelompok A2 di TK Dharma Wanita Tegal Gede yaitu ebaiknya guru membuat penilaian yang digunakan untuk mengetahui perkembangan anak secara spesifik. Seperti penilaian berupa bintang 1-4. Guru harus memahami 
membuat asesmen yang benar yang sesuai dengan capaian perkembangan anak berdasarkan indikator yang telah dibuat. Memberlakukan model portofolio agar lebih memahami perkembangan masing-masing anak dan dapat melatih kreatifitas anak.

\section{Daftar Pustaka}

[1] Waseso, Iksan. dkk. 2012. Evaluasi Pembelajaran TK. Edisi 1. Tangerang Selatan: Universitas Terbuka

[2] Zainul, Asmawi dan Agus Mulyana. 2007. Tes dan Asesmen di SD. Jakarta: Universitas Terbuka.

[3] Dariyanto. 2010. Media Pembelajaran Peranannya Sangat Penting Dalam Mencapai Tujuain Pembelajaran. Yogyakarta: Gava Media.

[4] Fridani, Lara. 2011. Evaluasi Perkembangan Anak Usia Dini. Jakarta : Universitas Terbuka.

[5] Sukmadinata, Nana Syaodih. 2009. Metode PenelitianPendidikan. Bandung: Remaja Rodakarya.

[6] Sukmadinata. 2011. Metode Penelitian Pendidikan. Bandung: Remaja Rosdakarya.

[7] Hasan, Iqbal. 2002. Pokok-pokok Materi Metodologi Penelitian dan Aplikasinya. Jakarta: Ghalia Indonesia

[8] Moleong, Lexy J. 2009. Metodologi Penelitian Kualitatif. Bandung: PT. Remaja Rosdakarya.

[9] Wahyudin, dkk. 2009. Pengantar Pendidikan. Jakarta: Universitas Terbuka.

[10] Sudjana, Nana. 2009. Penilaian Hasil Proses Belajar Mengajar Bandung: Remaja Rosdakarya

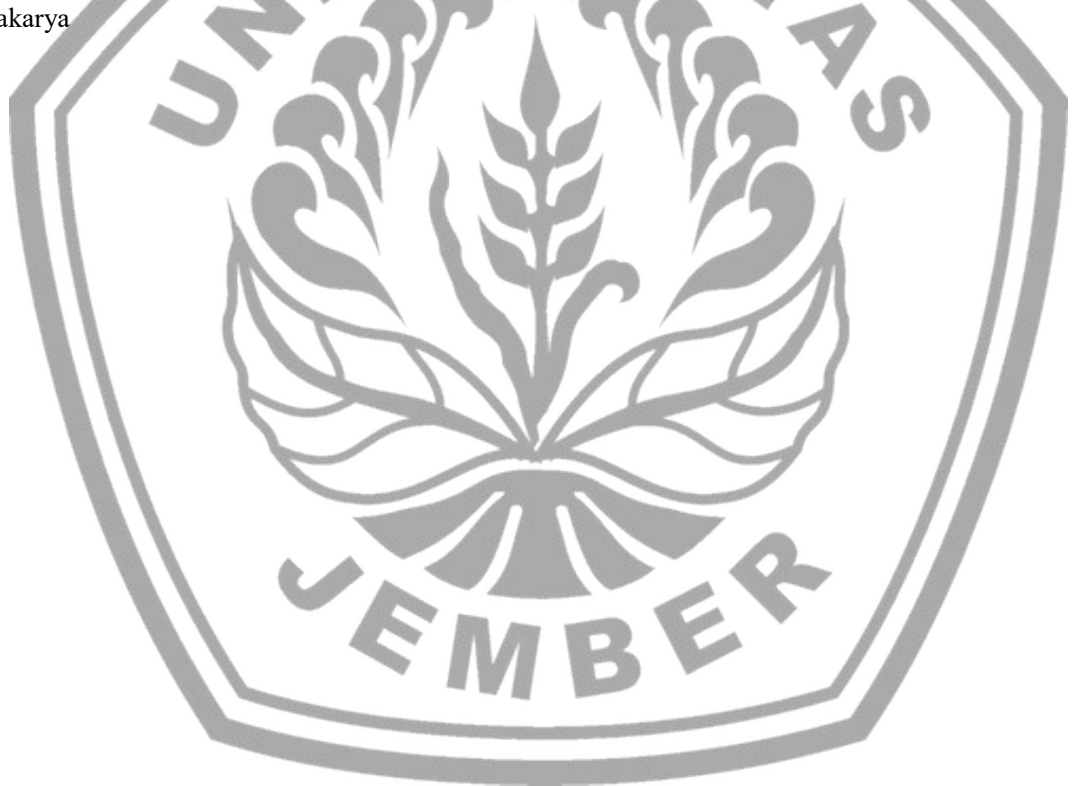

